\title{
Childhood Laryngeal Carcinoma
}

National Cancer Institute

\section{Source}

National Cancer Institute. Childhood Laryngeal Carcinoma. NCI Thesaurus. Code

C118811.

A rare carcinoma of the larynx that occurs during childhood. 